\title{
BONE AND SOFT TISSUE CHANGES IN PARAPLEGIC PATIENTS
}

\author{
By D. A. Hancock, G. W. Reed, P. J. Atkinson \\ Departments of Medical Physics and Oral Biology, University of Leeds \\ and \\ J. B. Cook and P. H. SMITH \\ Yorkshire Regional Spinal Injuries Unit, Pinderfields Hospital, Wakefield
}

\begin{abstract}
The loss of bone mineral in 66 paraplegic patients has been measured in the lower femoral shaft by scanning the leg with a beam of mono-energetic radiation from ${ }^{241} \mathrm{Am}$. The profile of the transmitted radiation was used to determine a parameter which was related to bone mass. The bone mass of paraplegic patients was significantly lower than normal. Persistent paralysis does not lead to a continued fall in bone mass, but once it has fallen, bone mass remains constant. Soft tissues also showed a muscle/ fat ratio that was lower than normal.
\end{abstract}

Key Words: Bone; Soft Tissue Calcification; Paraplegia.

\section{Introduction}

THE loss of mineral from the bones as a result of paralysis of the limbs is a wellknown phenomenon and has been observed in poliomyelitis (Whedon \& Shorr, 1957) as well as in paraplegia (Wright, 1965). In addition, calcification of the soft tissues is often found to be present in paraplegic patients. The extent of the related changes in calcification was the subject of a pilot study involving measurements of bone mass in patients from a paraplegic unit. Soft tissue measurements were also obtained at the particular site of measurement.

\section{Method}

The technique and equipment used for the measurement of bone mass have been described by West and Reed (1970) and several clinical applications have been reported (e.g. Atkinson \& West, I970; Atkinson, Hancock, Acharya, Parsons, Proctor \& Reed, I973). Briefly, a beam of mono-energetic radiation from the radio-isotope ${ }^{241} \mathrm{Am}$ is scanned across the lower thigh and the resulting profile of transmitted radiation is used to determine a parameter related to the bone mass; this is defined as the bone index ( $\mathrm{g} / \mathrm{cm}$ of bone mineral in the shaft) divided by the bone width. The method also gives a measure of the muscle to fat ratio in the soft tissue adjacent to the bone. Although the site is not ideal for detecting soft tissue calcification which usually occurs in the upper region of the femur, it was the one for which the apparatus was designed and for which information of bone and soft tissue changes in a range of clinical conditions had already been acquired.

Both in-patients and out-patients were measured if they had sufficient mobility and stability to sit in a chair. Thus, it was not possible to measure patients at the time of the most recent onset of paralysis. The duration of time between the date of injury and the first measurement ranged from 2 months to 31 years for a total of 66 patients. As well as these single measurements, it was 
also possible to repeat the measurements in 27 of the patients at periodic intervals over a period of approximately one year.

\section{Results}

Taken as a group, paraplegic patients were found to have a bone mass (i.e. bone index/bone width) significantly lower than for a normal population (Hancock, I974) and the muscle/fat ratio in the soft tissue adjacent to the femoral bone was also significantly lower than normal. No evidence of soft tissue calcification was detected at the site of measurement.

There were 17 patients ( 26 per cent) with a bone mass more than two standard deviations below the normal mean for their sex and age whereas in a normal population one would expect only 5 per cent of those measured to be so far below the mean (Tables I, 2 and 3). There was also a fairly marked difference in bone mass between patients with recent onset and those with long-standing paralysis (Tables I and 2). The median value of bone mass for the 66 patients was I.5I $4 \mathrm{~g} . \mathrm{cm}^{-3}$. For patients with a paralysis of less than 2 years' duration only 22 per cent ( 5 out of 23 ) had values of bone mass less than this median value. Of the other patients whose injuries had occurred more than 2 years before, 65 per cent had values less than the median. No difference was found between patients with upper and lower motor neurone lesions.

By measuring the bone mass periodically over a period of I year, it was possible to detect the changes occurring in individual patients. Twenty-seven patients were studied over a period of approximately I year and in the majority, who had relatively long-standing paralysis, no change in bone mass was recorded. However, three out of five patients with injuries of less than I year duration showed a significant reduction in bone mass.

\section{Discussion}

The results confirm that bone mass is in fact reduced after paralysis. Although by no means conclusive this study also showed that bone loss is not continuous and a tentative suggestion from the results could be that the bone loss usually occurred early after the onset of paralysis. Most patients with more than 2 years duration of paralysis showed a low bone mass compared with those with paralysis of shorter duration. This low bone mass could be explained by a loss occurring soon after paralysis. This is supported by the finding that continuing bone loss was present in patients with paralysis of less than I year duration and not in those with paralysis of longer duration.

The loss of calcium from the bones has of course been measured in patients after periods of resting in bed (Donaldson et al., 1970) and it has been postulated that muscle activity is associated with the normal mechanisms of maintaining bone mass (Bassett and Becker, 1962). However, this study shows that persistent paralysis does not lead to a continuing fall in bone mass and some other factor or factors are presumably involved in maintaining a constant but reduced bone mass. The results from this study suggest that early mobilisation is an essential factor in reducing bone loss in the early stages of paraplegia.

The lack of evidence of soft tissue calcification suggests that the site of measurement is not appropriate for its study in paraplegia. Since the effect on radiation transmission of soft tissue calcification would be in the opposite direction 
TABLE I

Bone index/bone width in patients with upper motor neurone lesions

\begin{tabular}{|c|c|c|c|c|c|}
\hline Patient & Sex & $\begin{array}{l}\text { Age } \\
\text { (yrs) }\end{array}$ & $\begin{array}{l}\text { Duration of } \\
\text { injury } \\
\text { (yrs) }\end{array}$ & & $\begin{array}{l}\text { ne index/ } \\
\text { ne width } \\
\text { g. } \mathrm{cm}^{-2} \text { ) }\end{array}$ \\
\hline F. C. & M & I 8 & $<\mathrm{I}$ & $2 \cdot 28$ & \\
\hline G. D. & $M$ & $2 \mathrm{I}$ & $<\mathrm{I}$ & $2 \cdot 2 \mathrm{I}$ & \\
\hline S. P. & $M$ & IO & $<\mathrm{I}$ & $\mathrm{I} \cdot \mathrm{I} 5$ & \\
\hline R. R.* & $\mathbf{M}$ & $5 \mathrm{I}$ & $<\mathrm{I}$ & $1 \cdot 52$ & \\
\hline S. S. & $\mathrm{F}$ & 27 & $<\mathrm{I}$ & $\mathrm{I} \cdot 87$ & \\
\hline D. Y. & $M$ & 31 & $<\mathrm{I}$ & $\mathrm{I} \cdot 85$ & \\
\hline J. W. & $\mathrm{F}$ & 16 & $<\mathrm{I}$ & $I \cdot 50$ & \\
\hline J. B. & $M$ & 27 & I & $I \cdot 5 I$ & \\
\hline B. C. & $\mathrm{F}$ & 49 & I & I.49 & \\
\hline M. C. & $\begin{array}{l}M \\
M\end{array}$ & 24 & I & I.9I & $>$ Mean $=I \cdot 84$ \\
\hline A. G. & $\begin{array}{l}M \\
M\end{array}$ & $\begin{array}{l}26 \\
63\end{array}$ & $\begin{array}{l}\text { I } \\
\text { I }\end{array}$ & $\begin{array}{l}2 \cdot 04 \\
\mathrm{I} \cdot 48\end{array}$ & \\
\hline J. G. & $\mathrm{M}$ & 29 & I & $\mathrm{I} \cdot 96$ & \\
\hline T. H. & $M$ & I9 & I & 2.49 & \\
\hline R. L. & $M$ & $2 I$ & I & $I \cdot 52$ & \\
\hline S. L. & M & 20 & I & $\mathrm{I} \cdot 93$ & \\
\hline K. M. & $M$ & 37 & I & 2.03 & \\
\hline D. P. & $M$ & 38 & I & $2 \cdot 36$ & \\
\hline G. P. & $\mathrm{M}$ & I 8 & I & $I \cdot 80 \mathrm{~J}$ & \\
\hline D. F. & F & 33 & 2 & $\mathrm{I} \cdot 28$ & \\
\hline R. M. & M & 50 & 2 & $\mathrm{I} \cdot 85$ & \\
\hline P. B. & $\mathbf{M}$ & 3.2 & 3 & $\mathrm{I} \cdot 27$ & \\
\hline P. C. & M & 22 & 3 & $\mathrm{I} \cdot 89$ & \\
\hline D. D. & $M$ & 23 & 3 & $\mathrm{I} \cdot \mathrm{I} 4$ & \\
\hline I. F. & M & I5 & 3 & 0.85 & \\
\hline E. A. & $\mathrm{F}$ & 38 & 4 & $I \cdot I 2$ & \\
\hline $\begin{array}{l}\text { G. H. } \\
\text { R. I. }\end{array}$ & $\begin{array}{l}M \\
M\end{array}$ & $\begin{array}{l}22 \\
23\end{array}$ & $\begin{array}{l}4 \\
4\end{array}$ & $\begin{array}{l}I \cdot 08 \\
I \cdot 3 I\end{array}$ & \\
\hline G. M. & $\mathrm{M}$ & 38 & $\begin{array}{l}4 \\
4\end{array}$ & $\mathrm{I} \cdot 50$ & \\
\hline F. P. & M & 45 & 4 & $\mathrm{I} \cdot 37$ & \\
\hline J. B. & $\mathrm{M}$ & 55 & 5 & $2 \cdot 46$ & $>$ Mean $=I \cdot 45$ \\
\hline Т. O. & M & 36 & 5 & I $\cdot 00$ & \\
\hline D. W. & M & $5 \mathrm{I}$ & 5 & $0.8 \mathrm{I}$ & \\
\hline A. D. & M & 37 & 6 & I.04 & \\
\hline N. W. & M & 27 & 6 & $\mathrm{I} \cdot 68$ & \\
\hline B. B. & M & 28 & 8 & $\mathrm{I} \cdot 63$ & \\
\hline A. D. & M & 35 & 9 & $\mathrm{I} \cdot 50$ & \\
\hline A. J. & $M$ & 32 & 9 & $\mathrm{I} \cdot 47$ & \\
\hline J. G. & $M$ & 30 & 12 & I.34 & \\
\hline E. S. & $\begin{array}{l}M \\
M\end{array}$ & $\begin{array}{l}3 \mathrm{I} \\
2 \mathrm{I}\end{array}$ & I2 & $\begin{array}{l}\mathrm{I} \cdot 57 \\
\mathrm{I} \cdot 20\end{array}$ & \\
\hline B. K. & $\mathrm{M}$ & $\begin{array}{l}31 \\
38\end{array}$ & $\begin{array}{l}13 \\
14\end{array}$ & $\mathrm{I} \cdot 44$ & \\
\hline A. I.* & M & 46 & 16 & 2.08 & \\
\hline
\end{tabular}

$\star$ Retention of some voluntary power below the level of the lesion. 
TABLE II

Bone index/bone width in patients with lower motor neurone lesions

\begin{tabular}{|c|c|c|c|c|c|}
\hline Patient & Sex & $\begin{array}{l}\text { Age } \\
\text { (yrs) }\end{array}$ & $\begin{array}{l}\text { Duration of } \\
\text { injury } \\
\text { (yrs) }\end{array}$ & \multicolumn{2}{|c|}{$\begin{array}{l}\text { Bone index/ } \\
\text { bone width } \\
\left(\text { g. } \mathrm{cm}^{-2}\right)\end{array}$} \\
\hline A. L. * & M & 46 & $<\mathrm{I}$ & $2 \cdot 38$ & \\
\hline A. W. & $M$ & 26 & $<\mathrm{I}$ & $I \cdot 71$ & Mean $=\mathrm{I} \cdot 85$ \\
\hline P. H. & F & 37 & I & $I \cdot 60$ & \\
\hline W. K.` & M & 62 & I & $I \cdot 69$ & \\
\hline J. B. & M & 28 & 2 & $2 \cdot 20$ & \\
\hline W. B. & $M$ & $5 \mathrm{I}$ & 3 & $I \cdot 68$ & \\
\hline R. K. ${ }^{\star}$ & $M$ & 20 & 3 & $I \cdot 27$ & \\
\hline R. L.` & $M$ & 30 & 3 & $\mathrm{I} \cdot 75$ & \\
\hline J. F.* & $M$ & 36 & 5 & $I \cdot 4 I$ & \\
\hline C. B. & $\mathrm{F}$ & 26 & 6 & $\mathrm{I} \cdot 40$ & \\
\hline W. N.* & $\begin{array}{l}M \\
M\end{array}$ & 56 & 7 & $\mathrm{I} \cdot 73$ & \\
\hline $\begin{array}{l}\text { F. J. } \\
\text { S. C. }\end{array}$ & $\begin{array}{l}\mathrm{M} \\
\mathrm{F}\end{array}$ & $\begin{array}{l}51 \\
33\end{array}$ & $\begin{array}{l}10 \\
10\end{array}$ & $\begin{array}{l}\mathrm{I} \cdot 34 \\
\mathrm{I} \cdot 08\end{array}$ & \\
\hline E. H. & $M$ & 44 & 12 & $I \cdot 70$ & Mean $-\mathrm{I} \cdot 4 \mathrm{I}$ \\
\hline G. B. & $M$ & 35 & I4 & $\mathrm{I} \cdot 04$ & \\
\hline J. B. & $\mathrm{F}$ & 33 & I4 & $I \cdot 56$ & \\
\hline J. B. & $M$ & 58 & 17 & $I \cdot 52$ & \\
\hline F. H. & $M$ & 54 & I8 & $I \cdot 46$ & \\
\hline J. H. & M & $5 \mathrm{I}$ & I8 & $I \cdot 43$ & \\
\hline A. M. & M & 59 & I8 & 0.07 & \\
\hline J. M.^ & M & 50 & 20 & $I \cdot 40$ & \\
\hline H. M. & $M$ & 52 & $2 \mathrm{I}$ & $\mathrm{I} \cdot 74$ & \\
\hline L. M. & $M$ & 62 & $3 I$ & $\mathrm{I} \cdot 07$ & \\
\hline
\end{tabular}

$\star$ Retention of some voluntary power below level of lesion.

TABLE III

Bone index/bone width for a normal population

\begin{tabular}{|c|c|c|c|c|c|c|}
\hline \multicolumn{4}{|c|}{ Male } & \multicolumn{3}{|c|}{ Female } \\
\hline Age range & $\mathrm{N}$ & $\begin{array}{c}\text { Mean } \\
\left(\text { g. } \mathrm{cm}^{-2}\right)\end{array}$ & $\begin{array}{l}\text { Standard } \\
\text { deviation }\end{array}$ & $\overline{\mathrm{N}}$ & $\begin{array}{c}\text { Mean } \\
\left(\text { g. } \mathrm{cm}^{-2}\right)\end{array}$ & $\begin{array}{l}\text { Standard } \\
\text { deviation }\end{array}$ \\
\hline $10-20$ & I 8 & $I \cdot 64$ & 0.39 & 28 & $I \cdot 76$ & 0.29 \\
\hline $20-30$ & 65 & 2.05 & 0.30 & 32 & $\mathrm{I} \cdot 76$ & 0.20 \\
\hline $30-40$ & 40 & $2 \cdot 04$ & $0 \cdot 30$ & 27 & $\mathrm{I} \cdot 74$ & $0 \cdot 29$ \\
\hline $40-50$ & 78 & $\mathrm{I} \cdot 92$ & $0 \cdot 30$ & 36 & $\mathrm{I} \cdot 79$ & 0.21 \\
\hline $50-60$ & 43 & I 92 & $0 \cdot 3 I$ & 54 & $I \cdot 65$ & $0.25^{\circ}$ \\
\hline $60-70$ & 37 & $\mathrm{I} \cdot 84$ & $0 \cdot 47$ & 56 & $\mathrm{I} \cdot 54$ & 0.27 \\
\hline $70-80$ & 5 & 1.53 & $0 \cdot 17$ & 34 & $\mathrm{I} \cdot 32$ & 0.23 \\
\hline
\end{tabular}

to the effect of muscle disuse, the method is unlikely to detect other than a gross degree of calcification.

The further application of the method to this study of bone mineral changes in paraplegia would, it is suggested, require a modification of design of the 
apparatus so that, however immobile the patient, measurements might be made shortly after onset of the paralysis.

Acknowledgements. Financial support from the Medical Research Council is gratefully acknowledged and we thank Miss Janet Guthrie for technical help.

\section{RÉSUMÉ}

On a mesuré dans le corps fémoral plus bas de 66 malades paraplégiques la perte du minéral des os, en se servant d'un faisceau explorateur de radiation monoénergique dès ${ }^{241} \mathrm{Am}$. On a employé le profil de la radiation qui était transmise pour déterminer un paramètre par rapport à la masse de l'os. La masse de l'os des malades paraplégiques était considérablement au-dessous de la normale. La paralysie persistante ne mène pas au déclin continuant mais, ayant diminuée, la masse de l'os reste constante. Les tissus mous montraient aussi une proportion au-dessous de la normale entre les muscles et la graisse.

\section{ZUSAMMENFASSUNG}

Man hat den Verlust von Knochenmineral in 66 Paraplegikern in dem Unterschenkelkörper gemessen. Die Messungen wurde durch den Überblick des Beins mit monoenergischer Strahlung von ${ }^{241} \mathrm{Am}$ geleistet. Das Profil der übergetragten Strahlung wurde benützt, um ein Parameter festzustellen, welches zu der Knochenmasse in Bezug stand. Die Knochenmasse der Paraplegiker war erkeblich kleiner als normal. Andauernde Lähmung führt nicht zu einer fortgesetzten Verminderung in der Knochenmasse, aber einmal vermindert, bleibt die Knochenmasse unverändert. Das Weichgewebe zeigte auch ein Muskel/ Fett Verhältnis, das weniger alsnormal war.

\section{REFERENCES}

Atkinson, P. J. \& West, R. R. (1970). Loss of skeletal calcium in lactating women. F. Obstet. Gynaec. of Br. Commonzw., 77, 555-560.

Atrinson, P. J., Hancock, D. A., Acharya, V. N., Parsons, F. M., Proctor, E. A. \& REED, G. W. (1973). Changes in skeletal mineral in patients on prolonged maintenance dialysis. Brit. Med. F., 4, 519-522.

BAssetT, C. A. L. \& BeCKeR, R. O. (I962). Generation of electric potentials by bone in response to mechanical stress. Science, 137, 1063-1064.

Donaldson, C. L., Holley, S. B., Vogel, J. H., HattNer, R. S., Boyers, J. H. \& McMillan, D. E. (1970). Effect of prolonged bed rest on bone mineral. Metabolism, I9, 107 I-IO84.

HANCOCK, D. A. (1974). Radiation absorption analysis of tissue composition in vivo. Ph.D. Thesis. University of Leeds.

WEST, R. R. \& REED, G. W. (I970). The measurement of bone mineral in vivo by photon beam scanning. Br. F. Radiol., 886-893.

WHEDON, G. \& SHORR, E. (I957). Metabolic studies in paralytic poliomyelitis. F. Clin. Invest., 36, 941-966.

Wright, V. (I965). Bone and joint changes in paraplegic men. Ann. Rheum. Dis., 24, 4I9-43I. 